\title{
Evidence of a predominance of sexual transmission of HTLV-1 in Salvador, the city with the highest prevalence in Brazil
}

\author{
David Nunes ${ }^{1}$, Ney Boa-Sorte ${ }^{1}$, Maria Fernanda Rios Grassi ${ }^{1,2}$, Kleber Pimentel', Maria Gloria Teixeira ${ }^{3}$, \\ Mauricio L Barreto ${ }^{3}$, Inês Dourado ${ }^{3}$, Bernardo Galvão-Castro ${ }^{1,2^{*}}$ \\ From 17th International Conference on Human Retroviruses: HTLV and Related Viruses \\ Trois llets, Martinique. 18-21 June 2015
}

Several investigations in Latin America have monitored health problems in urban spaces using what is called "sentinel areas" On the basis of this strategy, we detected an overall HTLV-1 prevalence of $1.7 \%$ in a representative sample of general population in Salvador, Northeast Brazil. In order to evaluate the sexual transmission of HTLV-1 in the general population of the city of Salvador, Northeast Brazil, the study analyzed a collection of 3,451 serum samples obtained by a simple random sampling procedure without replacement. Samples were in 30 "sentinel areas" $\mathrm{f}$ the city of Salvador, Bahia, Northeast Brazil collected from May 1998 to July 2000. HTLV-1 Syphilis and HIV infection were tested as a sexual transmission marker. Overall prevalence of HTLV-1 was $1.48 \%$ (51/3,451; 95\% CI: $1.10 \%-1.94 \%)$. Sixty-two percent of the seropositive individuals were women and the majority (65.3\%) earned two minimum wages or less. Overall prevalence of syphilis and HIV was $26.67 \%(45 / 3,451 ; 95 \%$ CI $1.08-2.25)$ and $0.6 \%$ $(21 / 3,451)$, respectively. Syphilis was present in 12 out of $51(23.53 \%)$ individuals infected by HTLV-1 (26\% of males and $19.35 \%$ of females), while only one person was infected with HIV (4.76\%). HTLV-1 infection was associated with family income (OR 2.25; 95\% CI $1.12-4.08$ ), age (OR 9.58; 95\% CI $5.01-18.29$ ) and syphilis (OR 38.63 ; $95 \%$ CI 15.08 - 98.94). In the logistic regression analysis stratified by sex, HTLV-1 infection remained associated with age and syphilis diagnosis in males and with age, income and syphilis diagnosis in females. These data strongly suggest a predominance of heterosexual

\footnotetext{
* Correspondence: bgalvao@bahiana.edu.br

'Centro Integrativo e Interdisciplinar de HTLV, Escola Bahiana de Medicina e Saúde Pública;Salvador-Bahia-Brazil

Full list of author information is available at the end of the article
}

transmission of HTLV-1 in Salvador, Bahia. Furthermore, the majority of infected individuals were poor, had low levels of education and lived in worse living conditions, confirming our previous results.

\section{Authors' details}

${ }^{1}$ Centro Integrativo e Interdisciplinar de HTLV, Escola Bahiana de Medicina e Saúde Pública;Salvador-Bahia-Brazil. ${ }^{2}$ Laboratório Avançado de Saúde Pública, Centro de Pesquisas Gonçalo Moniz, Fundação Oswaldo Cruz, Salvador, Bahia, Brazil. ${ }^{3}$ Instituto de Saúde Coletiva, Universidade Federal da Bahia, Salvador, Brazil.

Published: 28 August 2015

doi:10.1186/1742-4690-12-S1-03

Cite this article as: Nunes et al:: Evidence of a predominance of sexual transmission of HTLV-1 in Salvador, the city with the highest prevalence in Brazil. Retrovirology 2015 12(Suppl 1):O3.

Submit your next manuscript to BioMed Central and take full advantage of:

- Convenient online submission

- Thorough peer review

- No space constraints or color figure charges

- Immediate publication on acceptance

- Inclusion in PubMed, CAS, Scopus and Google Scholar

- Research which is freely available for redistribution

Submit your manuscript at www.biomedcentral.com/submit
() Biomed Central 